\title{
Eesti keele lühikeste klusiilide häälduse variatsioon ja seda mõjutavad tegurid
}

\author{
Liis Ermus \\ Eesti Keele Instituudi arhiivihaldur-nooremteadur \\ liis.ermus@eki.ee
}

\begin{abstract}
Teesid: Artikli eesmärk on akustiliselt kirjeldada eesti keele lühikeste intervokaalsete klusiilide hääldust. Uurimus keskendub klusiilidele sagedasemates täistähenduslikes sõnades. Vaadeldakse koartikulatsioonist tingitud allofoonilist varieerumist ja selle võimalikke mõjureid. Foneemide kestused on seotud peamiselt häälduskohaga. Allofooniline jagunemine ja kestused sõltuvad mõnevõrra vokaalkontekstist, samas rõhu mõju on vähene, avaldudes vaid allofoonilises jagunemises. Kõige rohkem redutseerus velaarne klusiil [k], samas on selle kestused stabiilsed. Suurimad kestuserinevused nii allofoonide kui ka vokaalkontekstide võrdluses on alveolaarsel klusiilil [t].
\end{abstract}

Märksõnad: akustiline foneetika, eesti keel, helilisus, klusiilid, koartikulatsioon, reduktsioon, spontaanne kõne

\section{Sissejuhatus}

Seotud kõnes ei realiseeru häälikud enamasti täielikult, vaid nende hääldus muutub koartikulatsiooni mõjul. Koartikulatsioon ehk kaasahääldus on ühe artikulatoorse segmendi mõju teistele lähedalasuvatele segmentidele. Selle tulemusena muutuvad lähedalasuvad segmendid üksteise sarnaseks. Kõne redutseerumise määr sõltub nii füsioloogilistest kui ka keelespetsiifilistest teguritest. Häälduse nõrgenemist seotud kõnes on seletatud kõnesituatsiooni ja vähima pingutuse printsiibiga (nt Lindblom 1990) - igapäevakõnes on hääldus ebatäpsem kui ette loetud tekstis. Hääldusžestide ulatus väheneb, žestid võivad omavahel kattuda või seguneda. Häälikuklassist, aktiivsest artikulaatorist, samuti ümbritsevatest häälikutest sõltub, millised häälikut iseloomustavad tunnused kõnes muutuvad.

Klusiilid kuuluvad frikatiivide ja afrikaatidega obstruentide klassi - need on häälikud, mille tekitamisel tekib kõnetraktis õhuvoolu liikumist takistav 
täielik või osaline ahtus. Enamasti on obstruendid helitud, helilised obstruendid moodustavad helitutega keeles sageli fonoloogilise vastanduse. Klusiilid (ja afrikaadid) erinevad teistest häälikutest selle poolest, et nende hääldus ei ole staatiline. Artikulatoorselt on klusiili hääldamisel eristatavad kolm faasi: sulu moodustamine (implosioon), sulu hoidmine (oklusioon), mille jooksul rõhk kõnetraktis suureneb, kuni see lõppeb sulu vallandumisega (eksplosioon). Akustiliselt on eristatavad sulufaas ja vallandumisfaas. (Ladefoged 2001) Suluosa võib olla helitu, poolheliline või heliline. Vallandumisfaasi akustiliseks iseloomustamiseks on kasutusel mõiste helilisusviive (voice onset time - VOT) - aeg, mis kulub sulu vallandumisest järgmise hääliku helilisuse või harmooniliste võngete tekkimiseni (Cho \& Ladefoged 1999).

Klusiilide häälduses väljendub häälduse nõrgenemine peale kestuste lühenemise peamiselt helilisuse varieerumises - helitud klusiilid muutuvad helilisemaks ja helilised vastupidi helitumaks. Esineb VOT lühenemist või negatiivseks muutumist (helilisus ilmub juba sulu vallandumise ajal või enne seda) ning ka vallandumisfaasi täielikku kadu.

\section{Sulghäälikute fonatsioon}

Klusiilide häälduse nõrgenemine sõnasiseses positsioonis tundub olevat universaalne tendents, kuigi keelte vahel on erinevusi olenevalt keeles kasutusel olevast vastandamiskriteeriumide hulgast ja vastandust kandvast positsioonist (sõnaalguline või sõnasisene) (Keating \& Linker et al. 1983). Redutseeruvad pigem häälikud neis positsioonides, mis vastandust ei kanna. Helilisusvastandust kasutavate keelte sõnasisesed klusiilid kannavad vastandust edasi enamasti kõigis positsioonides, redutseerub pigem heliline foneem (võib nõrgeneda kontinuandiks). Keeltes, kus helilisusvastandus puudub, ei teki regulaarseid variatsioone.

Sulufaasi fonatsiooni uurides eristatakse helilisi, helituid ja poolhelilisi sulufaase. Poolhelilise sulufaasi puhul mõõdetakse enamasti heliliseks muutumise määra. Davidson (2016) eristas osalise helilistumise neli tüüpi selle järgi, millises sulu osas helilisus ilmnes: eelneva hääliku helilisuse kandumine klusiili algusossa (bleed), negatiivne VOT (negative VOT) - helilisuse tekkimine enne sulu vallandumist, läbiv helilistumine (through) - kahe eelmise kombinatsioon, helilisuse ilmumine ja kadumine sulu jooksul (hump). Inglise keele seotud kõnes esinevad enamasti bleed-ja through-tüüp. 


\section{Vallandumisfaas}

Sulu vallandumise kestust ja laadi mõjutavad mitmed tegurid, mõned universaalsed, teised keelespetsiifilised. Taehong Cho ja Peter Ladefoged (1999) on reastanud järgmised klusiili häälduskohast tingitud aerodünaamilised mõjud (helitu) sulu vallandumise (ja helilisusviibe) kestusele: (1) sulu taguse ruumi maht - velaarse sulu taguses väiksemas ruumis tekib suurem rõhk, mille ühtlustamiseks (pärast vallandumist) ja häälekurdude võnkuma hakkamiseks läheb rohkem aega; (2) sulu esise ruumi maht - suurem õhumass velaarse sulu ees takistab sulu taguse rõhu langemist, mistõttu see võtab rohkem aega; (3) artikulaatorite kiirus - kiiremad artikulaatorid (nt keeleots võrreldes keele tagaosaga) võimaldavad sulu kiirema vallandumise ja sellega rõhu kiirema ühtlustumise suuruumis; (4) artikulatoorse kontakti ala sulu moodustamisel - suurem kontaktala (näiteks velaaridel) vallandub aeglasemalt, sest tekib Bernoulli efekt, mis vallandumisele vastu töötab; (5) glotaalse avanemise ulatus - velaari puhul on glotaalne ava väiksem ja seetõttu langeb rõhk aeglasemalt ning vallandumisfaas pikeneb; (6) sulu ja vallandumise kestuste vaheline temporaalne suhe - häälekurdude avatuna seismise aeg on piiratud ja seega järgneb pikemale sulule lühem vallandumine (Cho \& Ladefoged 1999: 213).

Mitmes keeles on täheldatud seotud kõnes vallandumisfaasi kadu. Nähtust on palju uuritud romaani keeltes, eriti palju hispaania keeles (nt Duez 1995; Hualde \& Simonet et al. 2011; Torreira \& Ernestus 2011). Enamasti peetakse sellist redutseerumist omaseks helilistele klusiilidele, kuid see esineb ka helitute puhul. Francisco Torreira ja Mirjam Ernestus (2011) võrdlesid mittetäielike sulgude esinemist hispaania ja prantsuse keele seotud kõnes ning leidsid, et hispaania keele Madridi dialektis esineb intervokaalsete helitute klusiilide vallandumisfaasi kadu üle $25 \%$ esinemisjuhtudest, samas prantsuse keeles vaid üle 5\%. Prantsuse keeles esinesid mittetäielikud sulud peamiselt sõna sees, kuid hispaania keeles ka sõnaalgulises positsioonis.

\section{Rõhu mõju}

Rõhu mõju uurimisel on keskendutud peamiselt kontrastiivse lauserõhu mõjule. Ilmnenud on üldkestuste ja VOT kestuste pikenemine, vallandumise suurem amplituud rõhulises positsioonis. Eristatakse kahte võimalikku käitumist rõhulises positsioonis. Esimene on ühtne tugevnemine (uniform strengthening) (nt de Jong 1995) - fonoloogilist kontrasti kandev tunnus muutub rõhu mõjul kontrasti kandva paari mõlema liikme puhul samamoodi. Teine võimalus on kontrasti võimendumine (contrast enhancement) (Cole \& Kim et al. 2007) - fonoloogilist 
kontrasti kandva paari liikmed käituvad rõhulises positsioonis nii, et kontrast oleks suurem - tugevad häälikud häälduvad veel tugevamalt ja nõrgad samas nõrgemalt. Ei ole samas leitud, et ühes keeles esineks vaid üks variant, samuti ei käitu kõik tunnused ühtmoodi. Suurem mõju on kontrastiivsel lauserõhul, mittekontrastiivne lauserõhk mõjutab kontrastiivseid tunnuseid vähe või üldse mitte. Inglise keele helilisusvastandust iseloomustavad tunnused (sulu kestus, VOT kestus, vallandumise amplituud) olid äärmuslikumad kontrastiivse rõhu korral, ehk ilmnes kontrasti võimendumine, samas mittekontrastiivne rõhk mõjutas oluliselt vaid VOT kestust (Cole \& Kim et al. 2007). Saksa keeles, kus esineb leenise ja fortise vastandus VOT kestuse ja sulu vallandumise intensiivsuse põhjal, leidsid Claudia Kuzla ja Mirjam Ernestus (2011), et sulu kestus oli pikem rõhulises positsioonis (fraasi piiril), samas fortise ja leeniste kestused omavahel olid lähedased (leenised vahel pikemadki). VOT kestus ja vallandumise intensiivsus olid rõhulises ja rõhuta positsioonis olulised fortiste korral, leeniste korral mõjutas vallandumise kestust vaid häälduskoht, rõhulise positsiooni mõju ei avaldunud.

\section{Vokaalkonteksti mõju}

Vokaalkonteksti mõjud klusiili hääldusele ja vastupidi sõltuvad artikulaatori liikuvusest ja selle osalusest ümberkaudsete vokaalide hääldamisel. Koartikulatsiooni füsioloogilised ja žestilised mudelid kirjeldavad hääldusžestide vähenemist ja kattumist (nt Moon \& Lindblom 1994; Fowler \& Saltzman 1993; Browman \& Goldstein 1992). Konsonandid ja vokaalid mõjutavad üksteist vastastikku. Koproduktsiooniteooria (nt Fowler \& Saltzman 1993) kohaselt sõltub kõnežestide mõju üksteisele sellest, kui palju kasutatakse üksteisele järgnevate häälikute jaoks samu artikulaatoreid. Mida väiksem see hulk on, seda vähem järgnevad häälikud üksteist mõjutavad. Väikseim mõju on žestides järjendil / $\mathrm{VpV/,} \mathrm{kus} \mathrm{kolmest} \mathrm{aktiivsest} \mathrm{artikulaatorist} \mathrm{(huuled,} \mathrm{keelekeha,}$ alalõug) on ühine vaid üks. Suurim vastastikmõju on aga järjendis /VkV/, kus žestid jagavad paljusid artikulaatoreid ja tekivad suuremad ruumilised hälbed.

Artikulatoorse piirangu (degree of articulatory constraint - DAC) (nt Recasens \& Pallarès et al. 1997) mudeli järgi on hääliku vastupanu koartikulatsioonile ja võime mõjutada ümberkaudseid häälikuid sõltuvuses keelekeha hõlmatusest hääliku moodustamisel. Mida suurem hõlmatus, seda vähem mõjutab koartikulatsioon vastavat häälikut ja häälik ise mõjutab sellevõrra rohkem ümbritsevaid. Erinevalt koproduktsiooniteooriast on velaarsed konsonandid selle käsitluse järgi koartikulatsioonile kõige vastupidavamad ning mõjutavad ka ümbritsevaid vokaale kõige rohkem. 


\section{Eesti keele klusiilid seotud kõnes}

Eesti keele sulghäälikud on helitud ja aspireerimata, sarnaselt teiste häälikutega võivad klusiilid esineda kolmes vältes. Kasutatakse fortise ja leenise (tugeva ja nõrga või pika ja lühikese) vastandust. Samas pole päriselt selge, kas vastandus peaks toimuma hääldusintensiivsuse või kestuse alusel (Eek \& Meister 1996). Ka eesti keeles on täheldatud lühikeste sõnasiseste klusiilide redutseerumist. Kõik seda kirjeldavad uurimused puudutavad intervokaalseid klusiile. Loetud sõnade puhul on täheldatud esimese ja teise silbi piiril olevate klusiilide heliliseks muutumist kuni 3/10 ulatuses (Ariste 1933). Kari Suomi ja Einar Meister (2012) leidsid loetud raamlausetes olevate sõnade uurimisel esimese ja teise silbi piiril asuvate lühikeste klusiilide täielikult heliliseks muutumist ja vallandumisfaasi kadu 5,9\% ulatuses kõigist esinemisjuhtudest, sealjuures velaari $[\mathrm{k}]$ hääldamisel oli vallandumisfaas kadunud 25,9\% juhtudest. Liis Raasik (2010) leidis nelja keelejuhi spontaankõne analüüsil, et lühikesed klusiilid muutuvad heliliseks väga sageli, kõigi vaadeldud foneemide puhul oli täielikult heliliseks muutunud üle $40 \%$ kõigist esinemisjuhtudest. Rõhu mõju on vaadelnud Kari Suomi ja Einar Meister (2012), kes leidsid, et fraasis rõhulises sõnas esinemine klusiilide kestust võrreldes rõhutus sõnas esinemisega oluliselt ei mõjutanud. Kontrastiivse rõhupositsiooni mõju oli suurem.

\section{Uurimisküsimused}

Käesolev artikkel jätkab Liis Raasiku (2010) alustatud tööd. Artikli eesmärk on akustiliselt kirjeldada lühikeste intervokaalsete klusiilide hääldust CVCVstruktuuriga täistähenduslikes sõnades, kus uuritav klusiil asub esimese ja teise silbi piiril. Üldisele kirjeldusele lisaks otsitakse vastust järgmistele küsimustele:

Kui suures ulatuses klusiilid redutseeruvad? Millised allofoonid redutseerumise tulemusel esinevad? Eeldatavalt esineb täistähenduslikes sõnades vähem redutseerumist kui spontaankõnes keskmiselt, aga rohkem kui loetud kõnes.

Mis mõju on klusiili sisaldava sõna sattumisel rõhulisse positsiooni? Eelnevad uurimused on näidanud sõnasisese sulghääliku kestuse pikenemist kontrastiivse lauserõhu korral, mittekontrastiivse lauserõhu mõju on vähene (Suomi \& Meister 2012).

Kas ja kuidas mõjutab erineva häälduskohaga klusiile vokaalne kontekst? Kas mõni häälduskoht on altim vokaalkonteksti muutustele ja milles see väljendub? Kas konsonandi ja vokaali häälduskohtade omavaheline kaugus mõjutab konsonandi kestust või allofoonilist esinemist? 


\section{Materjal ja meetod}

Materjal pärineb Tartu Ülikooli eesti keele spontaanse kõne foneetilisest korpusest (EKSKFK) ${ }^{1}$.

Korpuse dialoogid on salvestatud enamasti Tartu Ülikooli foneetikalabori helisalvestuskabiinis (varem Tartu Ülikooli ajakirjandusosakonna helistuudios), mõlemad kõnelejad eraldi kanalisse. Salvestatakse otse arvutisse wavformaadis lineaarsena resolutsiooniga $16 \mathrm{bit} / 44,1 \mathrm{kHz}$, signaale ei töödelda. Ühe salvestise kestus on umbes pool tundi.

Salvestus märgendatakse programmiga Praat (Boersma \& Weenink 2016). Sõnatasandi märgenduses kasutatakse automaatset kõnetuvastust, sõnatasand kontrollitakse ja häälikutasand märgendatakse käsitsi. Seejärel määratakse häälikustruktuurid, silbistruktuurid, kõnetaktid ja morfoloogilised kategooriad, dialoogiüksused, häälelaad, paralingvistilised nähtused ja muu (korpuse märgenduskihte vt joonis 1).

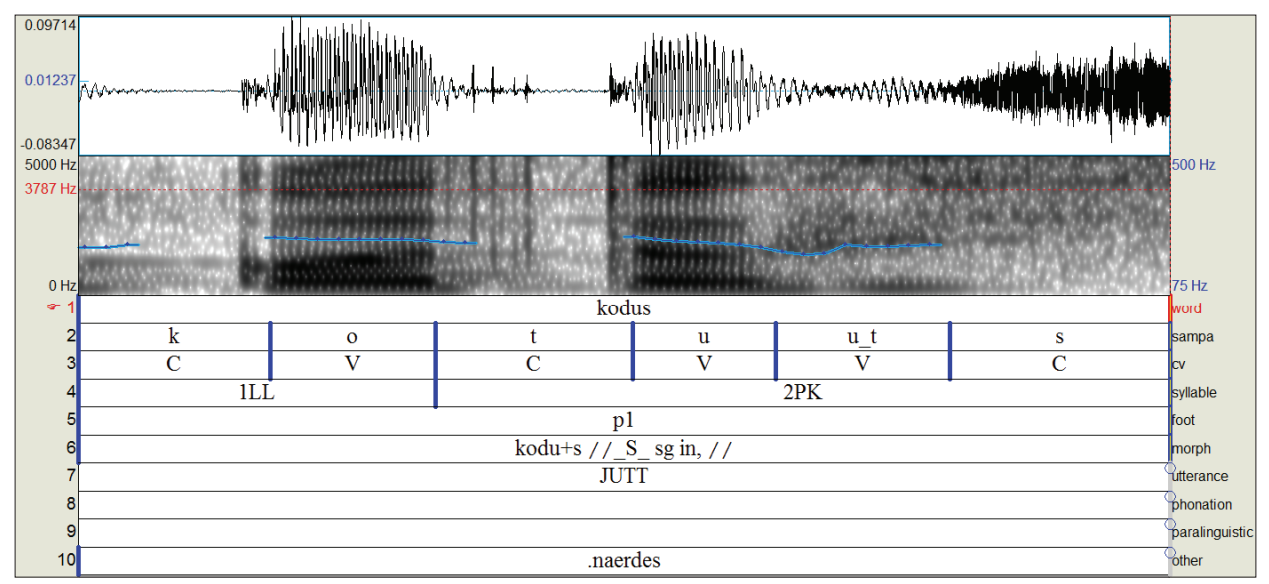

Joonis 1. Eesti keele spontaanse kõne foneetilise korpuse märgenduskihid.

Häälikutasandi märgenduses kasutatakse SAMPA transkriptsiooni (Wells 2015). Klusiili (korpuses märgendatakse ühekordsed klusiilid vastavalt $p, t$, k) alguspunti märgib perioodilise helilaine lõpp ja alumiste formantide kadumine; klusiili lõpp-puntiks on vallandumisfaasi järgselt perioodilise helilaine algus. Koartikulatsiooninähtuste ja hääldusmuutuste märkimiseks kasutatakse lisamärke. Näiteks helitu konsonandi täielikult heliliseks muutunud allofooni puhul on märgenduses kasutatud lisatähist_v, palatalisatsiooni märgitakse ülakomaga'. Geminaatkonsonandid jagatakse automaatselt skripti abil. 
Käesoleva uurimuse jaoks valiti korpuse tuhande sagedasema lemma hulgast vähemalt 50 korda esinevad täistähenduslikud sõnad (substantiivid, verbid, adjektiivid, numeraalid), mis sisaldavad esimese ja teise silbi piiril VCV (vokaal-konsonant-vokaal) positsioonis lühikest helitut sulghäälikut ([k], [p], [t]). Sõnad on otsitud korpuse avaliku otsingumootoriga (http://www.murre. ut.ee/otsing/ekskfk.php).

Välja jäid võõrsõnad, mille pearõhk oli järgsilbil ja sõnad, mille sobivaid vasteid on alla 20 (erandiks sõber). Vastete arvu vähendasid tüvemuutused, kus intervokaalne positsioon kadus (nt lugema: loen või sõber: sõbra). Eraldi on vaadeldud ühe lemma muutunud vokaalkontekstiga vorme (lemma tege vormid tege-, tegi-, lemma pida vormid pida-, pidi-). Kokku analüüsiti 1491 esinemisjuhtu. Esinemisjuhtude arv vaadeldud tüvede kaupa on toodud tabelis 1 .

Tabel 1. Analü̈̈situd tüvede arv klusiilide kaupa.

\begin{tabular}{|l|l|l|l|l|l|l|l|}
\hline & & & & & & & kokku \\
\hline [p] & luba & paber & sobi & sõber & tuba & vaba & \\
\hline & 36 & 23 & 34 & 14 & 26 & 39 & 172 \\
\hline [t] & kodu & kadu & nädal & pida & pidi & sada & \\
\hline & 108 & 26 & 134 & 80 & 95 & 45 & 488 \\
\hline [k] & luge & lugu & maga & nägi & tege* & tegi & \\
\hline & 127 & 55 & 60 & 90 & 235 & 264 & 831 \\
\hline kokku & & & & & & & $\mathbf{1 4 9 1}$ \\
\hline
\end{tabular}

*Tabeli ülevaatlikkuse huvides on tüved tege- ja tegele- esinemisjuhud liidetud. Tüve tege- esines 159 ja tüve tegele- 76 korda.

Faile töödeldi programmiga Praat (Boersma \& Weenink 2016). Kontrolliti üle olemasolev märgendus. Eemaldati juhud, kus spektrogrammi ei olnud võimalik analüüsida - samal ajal rääkis teine kõneleja, esines tugevaid kvaliteedimuutusi (sosin, kärin, naer), ning juhud, kus klusiili kõrval asuvat vokaali ei hääldatud. Kestused eraldati skriptiga. Mõõdeti järgmisi parameetreid: kestus, osaliselt helilise allofooni korral helilise faasi kestus ja asukoht (alguses, keskel, lõpus). Kui esines eristatav vallandumisfaas, mõõdeti sulufaasi ja vallandumisfaasi kestused. Kui allofoon ei olnud hääldatud klusiilina, siis märgiti täpsemalt hääldusviis. Märgiti ka sõna sattumine lauserõhulisse või rõhutusse positsiooni akustiliste tunnuste (intensiivsus, põhitoon) ja fraasistruktuuri alusel. Andmete analüüsil kasutati MS Exceli statistikamoodulit, erinevuste olulisus määrati ANOVA-testidega. 


\section{Tulemused}

\section{Allofooniline jaotus}

Eristusid täielikult realiseerunud allofoonid (eristatava vallandumisfaasiga) ja redutseerunud allofoonid. Vallandumisfaasiga (VOT) allofoonid jagunesid sulufaasi helilisuse osakaalu järgi helituks [C |VOT], poolheliliseks [C_v|C|VOT] ja heliliseks [C_v|VOT]. Redutseerunud allofoonide hulgas olid eristatavad ilma vallandumisfaasita heliline klusiil [C_v], frikatiivistunud allofoonid ${ }^{2}$ (frikatiivistunud vallandumisfaasiga klusiil [C $\mid \mathrm{fr}]$ ja täielikult frikatiivistunud allofoon), poolvokaal. Sagedasemate allofoonide spektrogrammid on esitatud joonisel $2(\mathrm{a}-\mathrm{d})$.

\section{Joonis $2 a$}

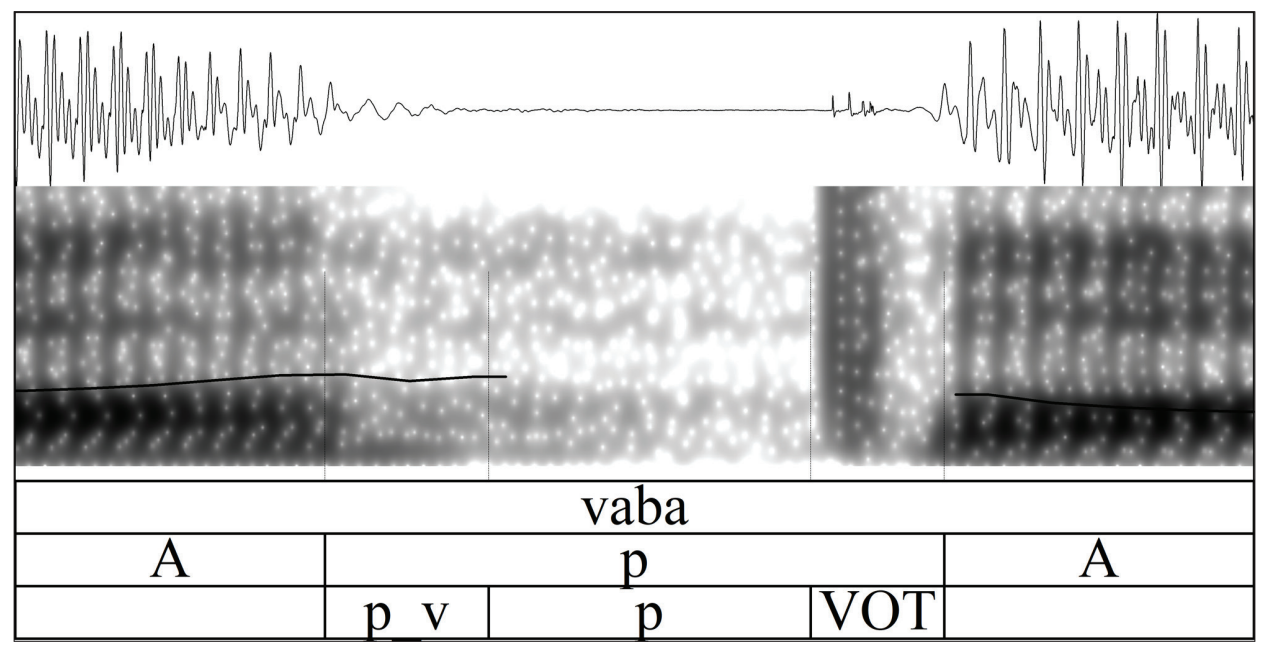

Joonis $2 b$

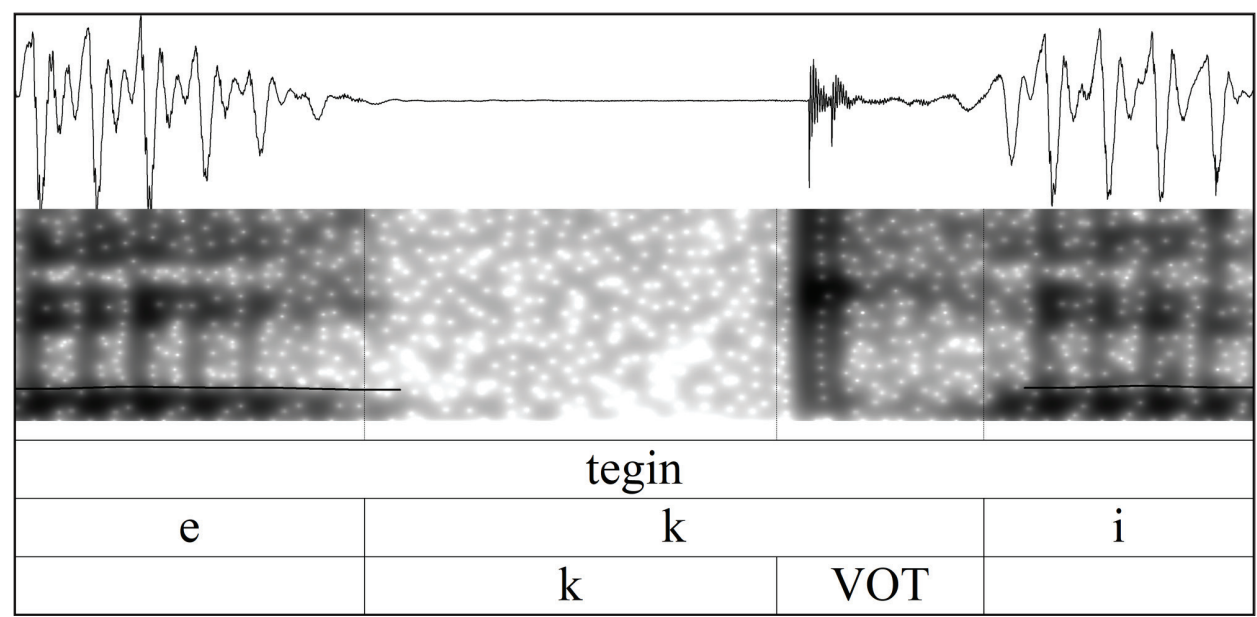


Joonis $2 c$

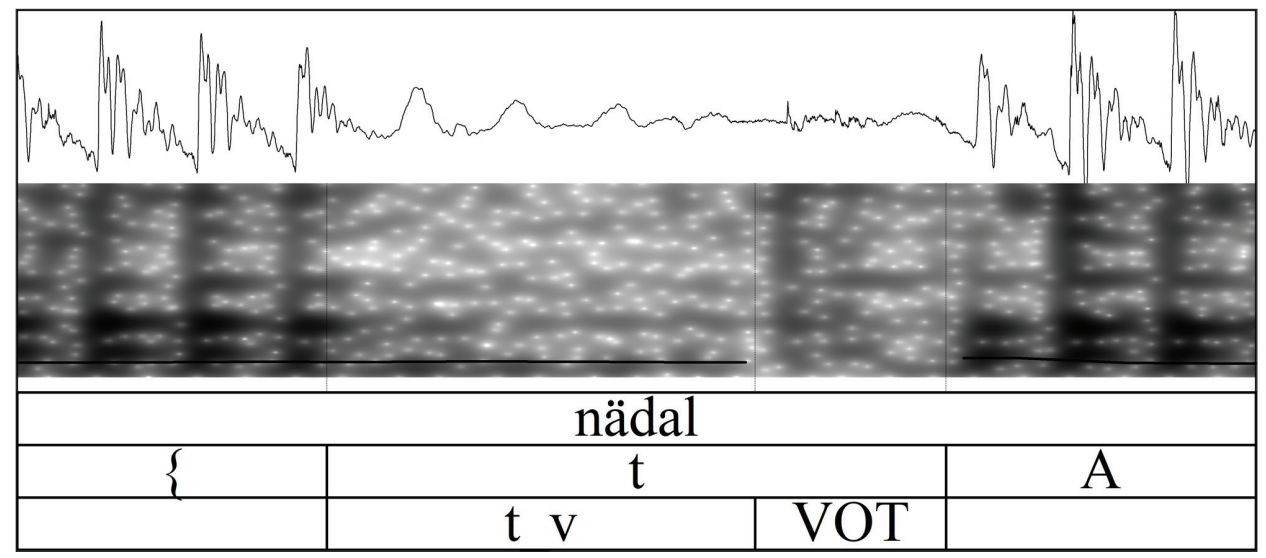

Joonis $2 d$

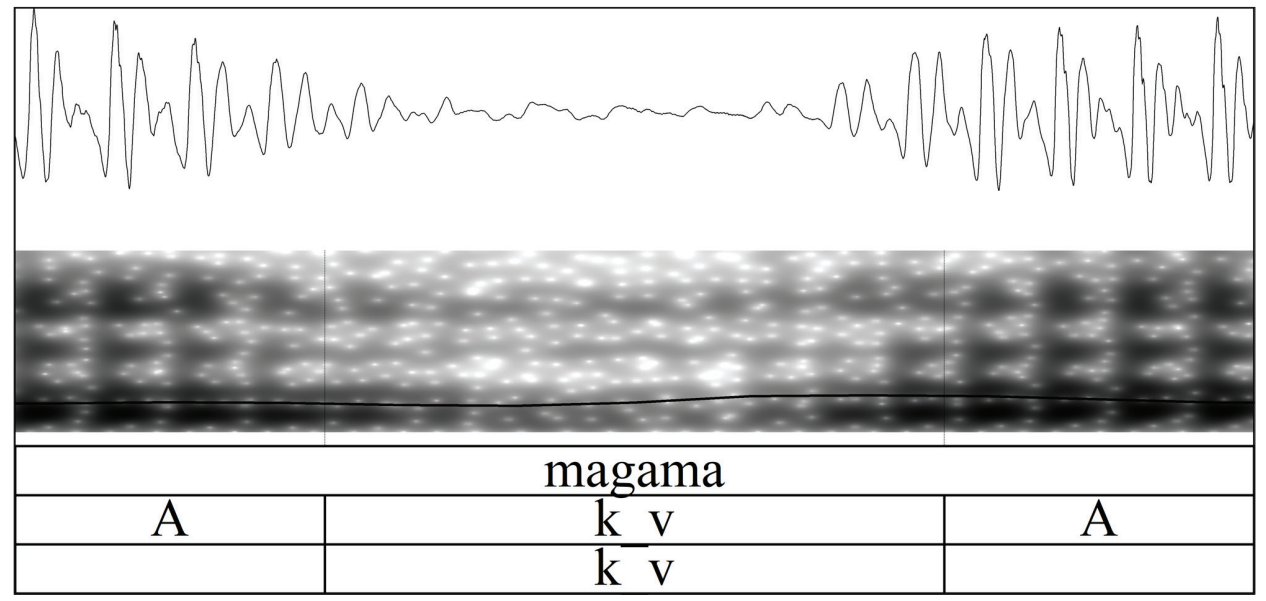

Joonis 2a-d. Sagedasemate allofoonide spektrogramminäited a) [p] poolheliline allofoon sõnas vaba; $b$ ) [k] helitu allofoon sõnas tegi; $c$ ) [t] heliline allofoon sõnas nädal; d) [k] redutseerunud heliline allofoon sõnas maga.

Allofooniline jaotus foneemide kaupa on toodud joonisel 3.

Allofoonilise jagunemise erinevus oli suurim redutseerunud allofoonide esinemisjuhtude hulgas. [t] ja [p] puhul olid ülekaalus vallandumisfaasiga allofoonid, [k] puhul esines aga üle pooltel juhtudest redutseerunud allofoone. [p] esinemisjuhtudest oli vallandumisfaasi kaoni redutseerunud $36 \%$, [t] omadest $30 \%$ ja [k] omadest $60 \%$.

Vallandumisfaasiga allofoonidest esines kõige vähem täiesti helitut allofooni - [p] puhul 19\% kõigist juhtudest, [t] ja [k] puhul vastavalt $10 \%$ ja $9 \%$. 


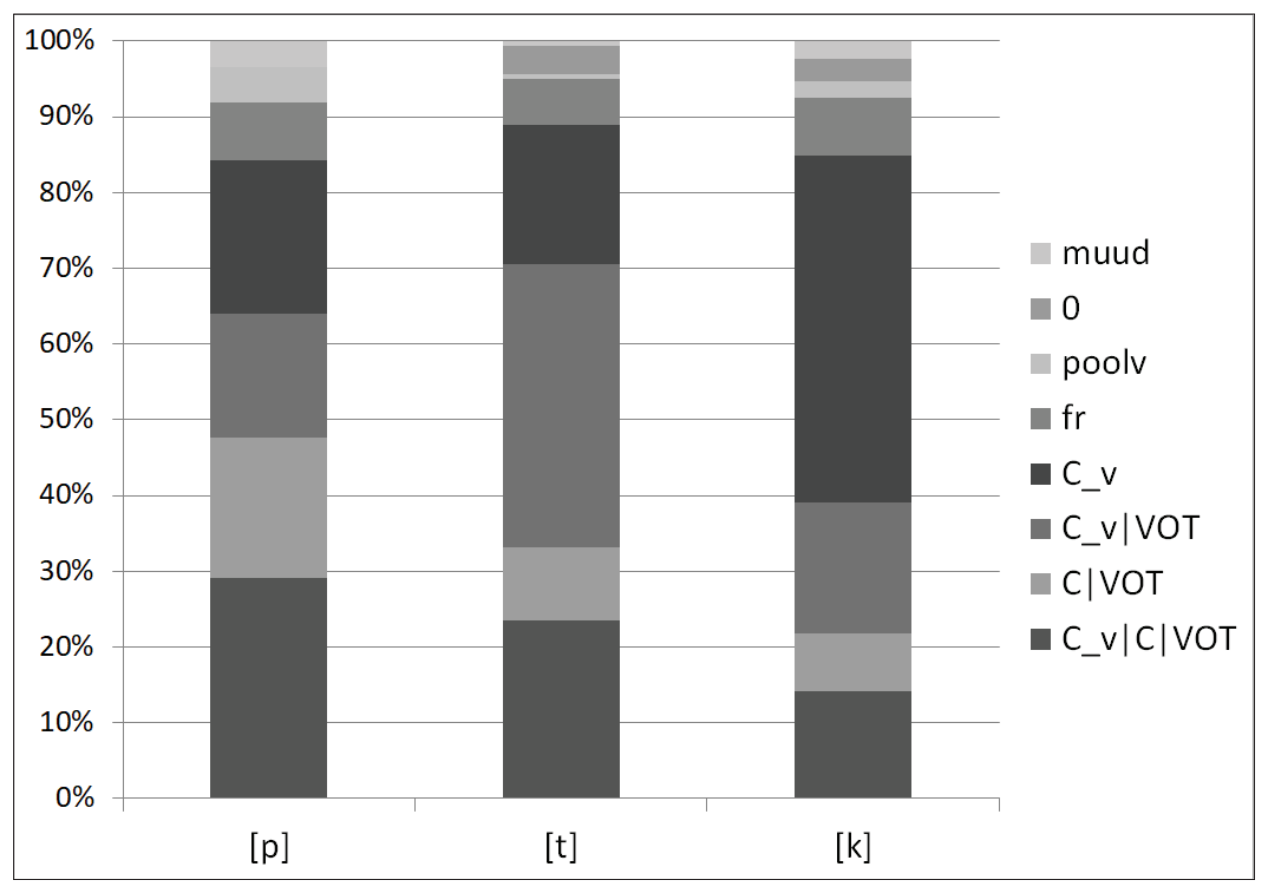

Joonis 3. Foneemide võrdlev allofooniline jagunemine kõigi esinemuste lõikes.

Poolhelilist allofooni esines kõige rohkem [p] puhul - peaaegu kolmandiku ulatuses kõigist esinemisjuhtudest. [t] esinemisjuhtudest moodustas poolheliline allofoon $24 \%$ ja [k] omadest $13 \%$. Helilist vallandumisfaasiga allofooni esines [p] ja [k] puhul peaaegu võrdselt, vastavalt $16 \%$ ja $18 \%$. Samas [t] esinemustes moodustas heliline vallandumisfaasiga allofoon $37 \%$ enamuse.

Redutseerunud allofoonide hulgas kerkis esile [k] helilise vallandumisfaasita allofooni sagedus - 46\% kõigist esinemisjuhtudest. [p] ja [t] puhul moodustas sarnane allofoon umbes viiendiku esinemistest. Frikatiivistunud allofoone esines $6-8 \%$. [p] puhul esines $5 \%$ ulatuses bilabiaalset poolvokaali [w] ja [k] puhul $2 \%$ ulatuses kahte poolvokaalset allofooni [w] ja [j], [t] puhul esines vähesel määral palataalset poolvokaali [j]. Kaoni redutseerunud oli 4\% [t] ja 6\% [k] esinemisjuhtudest, [p] puhul kadu ei esinenud. Juhuslikke allofoone esines paari protsendi ulatuses. 


\section{Kestused}

Kestuste variatsioon foneemide kaupa on esitatud joonisel 4.

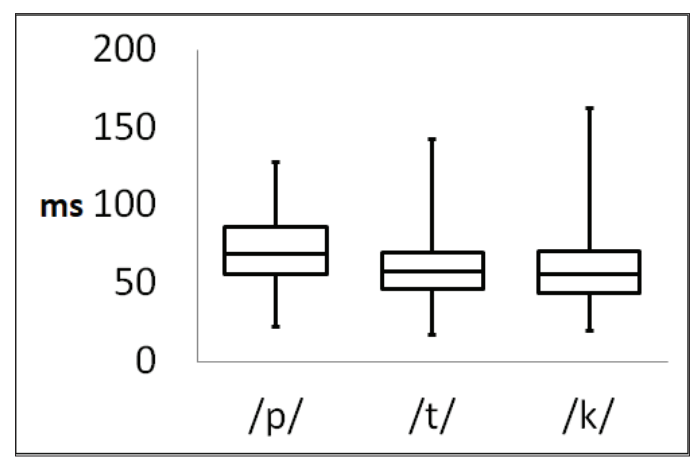

Joonis 4. Foneemide kestused millisekundites kõigi esinemuste lõikes.

Kui arvesse võtta kõik esinemused, oli kõige pikema keskmise kestusega [p] (med $69 \mathrm{~ms}$ ). [t] ja [k] kestused olid väga lähedased (med [t] $58 \mathrm{~ms}$ ja [k] $56 \mathrm{~ms}$ ), kuid see on ilmselt tingitud allofooniline jaotuse mõjust, allofoonide kaupa olid omavahel lähemad [p] ja [k] kestused. Märgatav on kestuste varieerumine. Kõige lühemad kestused jäid kõigi foneemide puhul 20 ms lähedale, kõige pikemad üle 120 ms. Suurim varieerumine oli [k] kestustes. Kestused kõigi esinemuste arvestuses erinesid oluliselt [p] ja teiste foneemide vahel $(\mathrm{p}<.0001)$.

Allofoonide kestuste omavahelised suhted olid foneemide võrdluses sarnased. Kestuste variatsioon allofoonide kaupa on esitatud joonisel 5 (a-c), keskmised kestused ja standardhälbed millisekundites tabelis 2 .

Tabel 2. Allofoonide keskmised kestused millisekundites (standardhälbed sulgudes).

\begin{tabular}{|l|l|l|l|l|l|l|l|l|}
\hline & C_v $\mid$ C $\mid$ VOT & C | VOT & C_v | VOT & C_v & fr & C | fr & poolv & kõik \\
\hline [p] & $88(16)$ & $77(17)$ & $67(16)$ & $54(11)$ & $61(14)$ & $71(13)$ & $50(17)$ & $71(21)$ \\
\hline [t] & $74(15)$ & $67(20)$ & $58(14)$ & $39(10)$ & $46(12)$ & $62(11)$ & $46(5)$ & $59(19)$ \\
\hline [k] & $81(20)$ & $76(17)$ & $66(15)$ & $47(10)$ & $58(17)$ & $74(16)$ & $41(11)$ & $59(21)$ \\
\hline
\end{tabular}

Kõige pikema kestusega olid poolhelilised allofoonid, neile järgnesid helitud ja helilised allofoonid. Kõige lühema kestusega olid helilised redutseerunud allofoonid, neist taas pikemad frikatiivistunud allofoonid. Kõige rohkem varieerus helitu allofooni kestus, üksikuid ekstreemseid kestusi esines ka poolhelilise ja helilise allofooni esinemustes. 
Joonis 5a

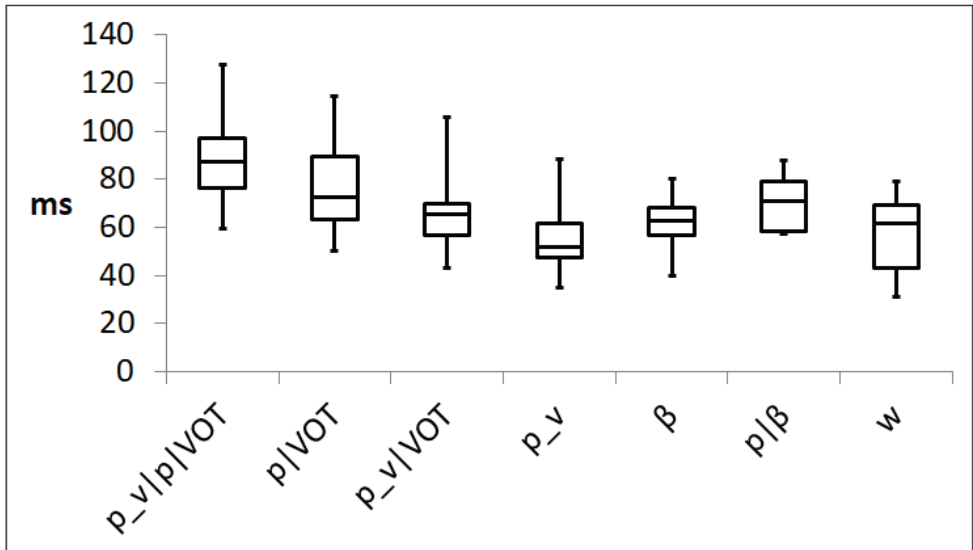

Joonis $5 b$

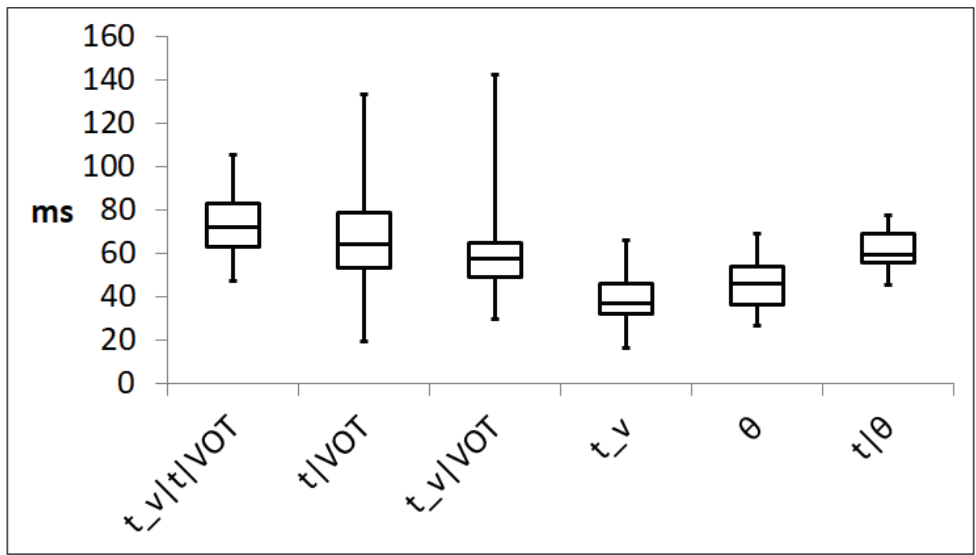

Joonis $5 c$

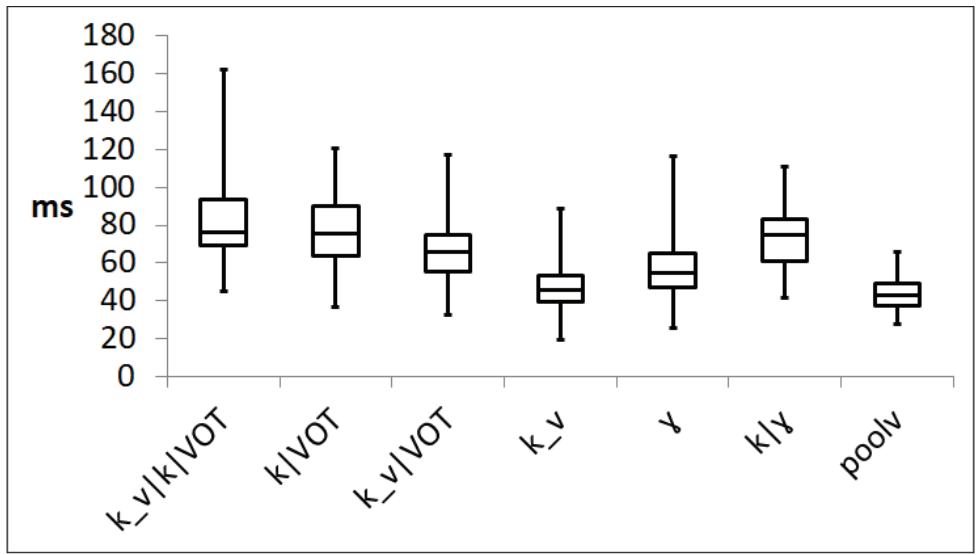

Joonis 5a-c. Allofoonide kestused foneemide kaupa millisekundites kõigi esinemuste lõikes: a) [p] allofoonid; b) [t] allofoonid; c) [k] allofoonid. 
Keskmised kestused ja mediaankestused olid enamasti lähedased, erandiks [k] poolheliline allofoon, mille keskmine kestus oli $81 \mathrm{~ms}$, kuid mediaankestus $76 \mathrm{~ms}$ (sarnane helitu allofooniga). Osaliselt frikatiivistunud allofoonide kestus oli enamasti lähedane helitu allofooni omaga, täiesti frikatiivistunud allofooni oma võrreldav redutseerunud helilise allofooni kestusega. Poolhelilise allofooni kestused erinesid kõigi foneemide vahel oluliselt $(\mathrm{p}<.01)$. Helitu allofooni kestused erinesid oluliselt $[\mathrm{k}]$ ja $[\mathrm{t}]$ vahel $(\mathrm{p}<.05)$. Helilise allofooni kestused erinesid oluliselt $[\mathrm{t}$ ] ja teiste foneemide vahel $(\mathrm{p}<.01)$, redutseerunud helilise allofooni kestused erinesid kõigi foneemide vahel oluliselt $(\mathrm{p}<.001)$.

Keskmine kestus üle kõigi esinemuste peegeldas $[t] \mathrm{ja}[\mathrm{k}]$ puhul sagedasima allofooni kestust ([k_v] ja [t_v|VOT]), [p] puhul, kus allofoonide jaotumine oli ühtlasem, jäi kõigi esinemuste keskmine helitu allofooni oma lähedale.

Vallandumisfaasiga allofoonide faaside keskmiste kestuste võrdlus on esitatud tabelis 3 .

Tabel 3. Vallandumisfaasiga allofoonide sulufaasi ja vallandumisfaasi keskmised kestused millisekundites (standardhälbed sulgudes).

\begin{tabular}{|l|l|l|l|l|l|l|l|l|}
\hline & C_v|C | VOT & & C | VOT & & C_v|VOT & & kõik & \\
\hline & sulg & VOT & sulg & VOT & sulg & VOT & sulg & VOT \\
\hline [p] & $66(15)$ & $23(9)$ & $55(16)$ & $22(7)$ & $45(12)$ & $22(9)$ & $57(17)$ & $22(8)$ \\
\hline [t] & $53(15)$ & $21(6)$ & $40(17)$ & $27(12)$ & $35(11)$ & $23(10)$ & $42(16)$ & $23(9)$ \\
\hline$[\mathbf{k}]$ & $51(15)$ & $29(12)$ & $44(12)$ & $33(10)$ & $38(13)$ & $32(12)$ & $44(15)$ & $29(11)$ \\
\hline
\end{tabular}

Kõige pikema kestusega olid poolhelilise allofooni suluosad. Foneemide võrdluses olid lähedasemad [k] ja [t] allofoonide suluosad. [p] sulgude kestused olid kõigil juhtudel kõige pikemad, eriti suur oli erinevus poolhelilise allofooni puhul. Kõigi foneemide poolhelilise allofooni sulu helilise ja helitu faasi keskmised kestused olid omavahel peaaegu võrdsed.

Vallandumisfaaside kestused olid lähedasemad [p] ja [t] vahel. Kõige pikemad vallandumisfaasid olid [k] allofoonidel. Kõige pikemad olid helitu allofooni vallandumise kestused, (v.a [p]). [t] puhul olid lähedasemad poolhelilise ja helilise allofooni vallandumised, $[\mathrm{k}]$ puhul helitu ja helilise allofooni omad. Kõige väiksem erinevus sulu ja vallandumise kestuses oli [k] allofoonides. Kõigi allofoonide puhul ja ka üle kõigi esinemuste olid statistiliselt oluliselt erinevad $[\mathrm{k}]$ vallandumised $(\mathrm{p}<.01)$, helitu allofooni vallandumiste kestused olid oluliselt erinevad kõigi foneemide vahel $(\mathrm{p}<.01)$. 


\section{Rõhu ja vokaalkonteksti mõju}

Rõhuliseks märgiti nii fraasirõhulises kui ka kontrastiivse rõhu positsioonis olevad sõnad. Kuna kontrastiivset rõhku esines väga vähe, on edaspidi vaadeldud kõiki rõhulisi positsioone koos. Rõhulises ja rõhuta positsioonis esines umbes sama palju sõnu (778 vs 713). [p] ja [k] esinesid rõhulises positsioonis rohkem, eriti suur oli vahekord rõhulise positsiooni kasuks [p] puhul ([p] 120 vs 52, [k] 438 vs 393). [t] esines rohkem rõhutus positsioonis (220 vs 268).

Allofoonide protsentuaalne jagunemine rõhulises ja rõhuta positsioonis on toodud joonisel 6 .

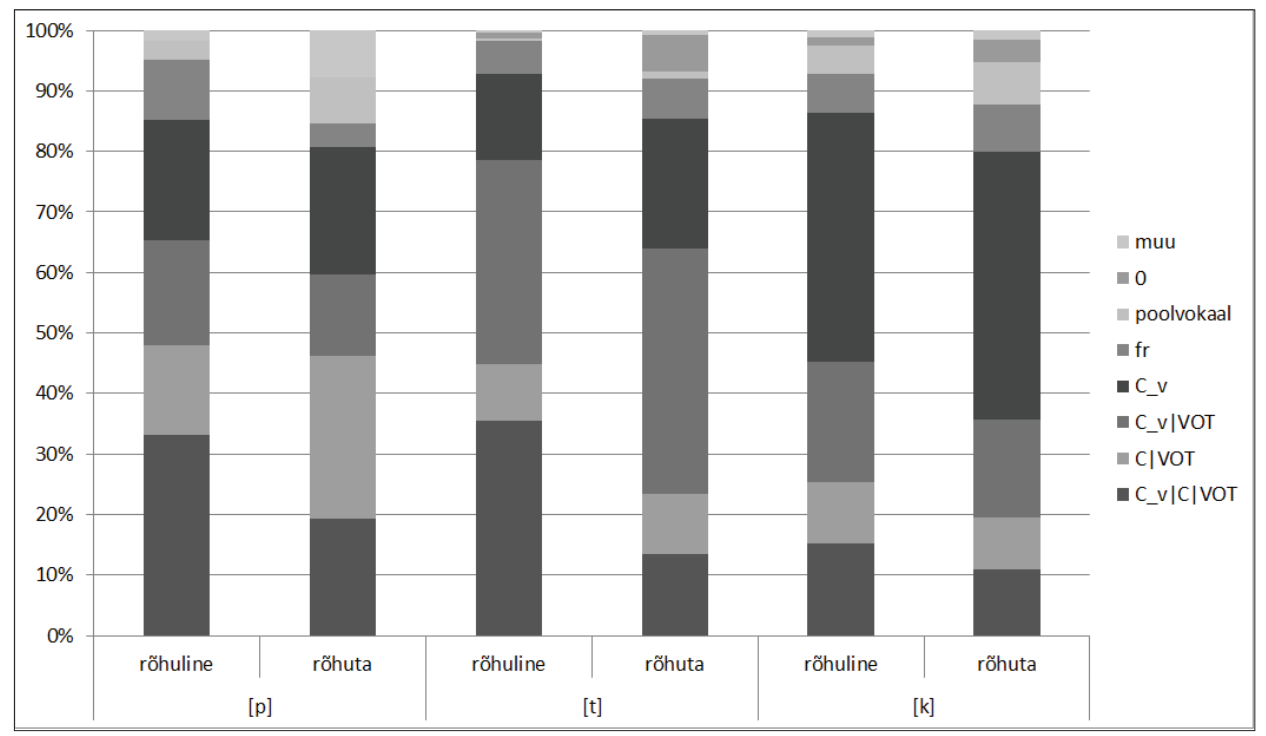

Joonis 6. Foneemide võrdlev allofooniline jagunemine rõhulises ja rõhuta positsioonis.

Allofooniline jaotus näitas vähest seotust rõhulise positsiooniga. Rõhulises positsioonis esines ootuspäraselt rohkem helituid ja poolhelilisi allofoone, rõhutus rohkem redutseerunud allofoone. Suurimad erinevused rõhulise ja rõhuta positsiooni vahel olid [t] allofoonilises jagunemises ja kõige väiksemad [k] omas. Suurim erinevus oli [t] poolhelilise allofooni hulgas. Ka täielikku kadu esines rohkem rõhuta positsioonis, suurim erinevus taas [t] puhul.

Allofoonide keskmised kestused rõhulises ja rõhuta positsioonis on esitatud tabelis 4 . 
Tabel 4. Sagedasemate allofoonide keskmised kestused millisekundites rõhulises ja rõhuta positsioonis (standardhälbed sulgudes).

\begin{tabular}{|l|l|l|l|l|l|l|}
\hline & [p] & & {$[\mathbf{t}]$} & & {$[\mathbf{k}]$} & \\
\hline & rõhuline & rõhuta & rõhuline & rõhuta & rõhuline & rõhuta \\
\hline C_v|C|VOT & $88(15)$ & $88(19)$ & $74(15)$ & $75(15)$ & $77(17)$ & $83(21)$ \\
\hline C|VOT & $77(23)$ & $76(17)$ & $73(23)$ & $65(17)$ & $76(17)$ & $79(20)$ \\
\hline C_v|VOT & $69(16)$ & $61(5)$ & $58(14)$ & $58(12)$ & $66(17)$ & $66(13)$ \\
\hline C_v & $54(11)$ & $55(13)$ & $41(10)$ & $31(11)$ & $48(11)$ & $47(10)$ \\
\hline kõik & $72(20)$ & $69(20)$ & $60(19)$ & $55(18)$ & $58(20)$ & $58(20)$ \\
\hline
\end{tabular}

Rõhuline positsioon mõjutas kestusi vähe. Üldkestuste vahe puudus täiesti [k] puhul, kõige suurem oli aga [t] puhul. Rõhulises positsioonis olid kestused veidi pikemad. Kõige suuremad erinevused ilmnesid [t_v] puhul (rõhuline $41 \mathrm{~ms}$, rõhuta $31 \mathrm{~ms}$ ), [p_v | VOT] ja [t|VOT] olid rõhulises positsioonis keskmiselt $8 \mathrm{~ms}$ pikemad. Samas $[\mathrm{k}]$ mõnede allofoonide puhul oli rõhuta positsioonis keskmine kestus pikem, nt poolheliline allofooni keskmine kestus oli rõhuta positsioonis tervelt $6 \mathrm{~ms}$ pikem. Ükski kestuserinevus ei olnud statistiliselt oluline ( $\mathrm{p}>.05$ ).

Allofoonide protsentuaalne jagunemine foneemide kaupa eelneva ja järgneva vokaali järgi on esitatud joonisel $7(\mathrm{a}-\mathrm{c})$.

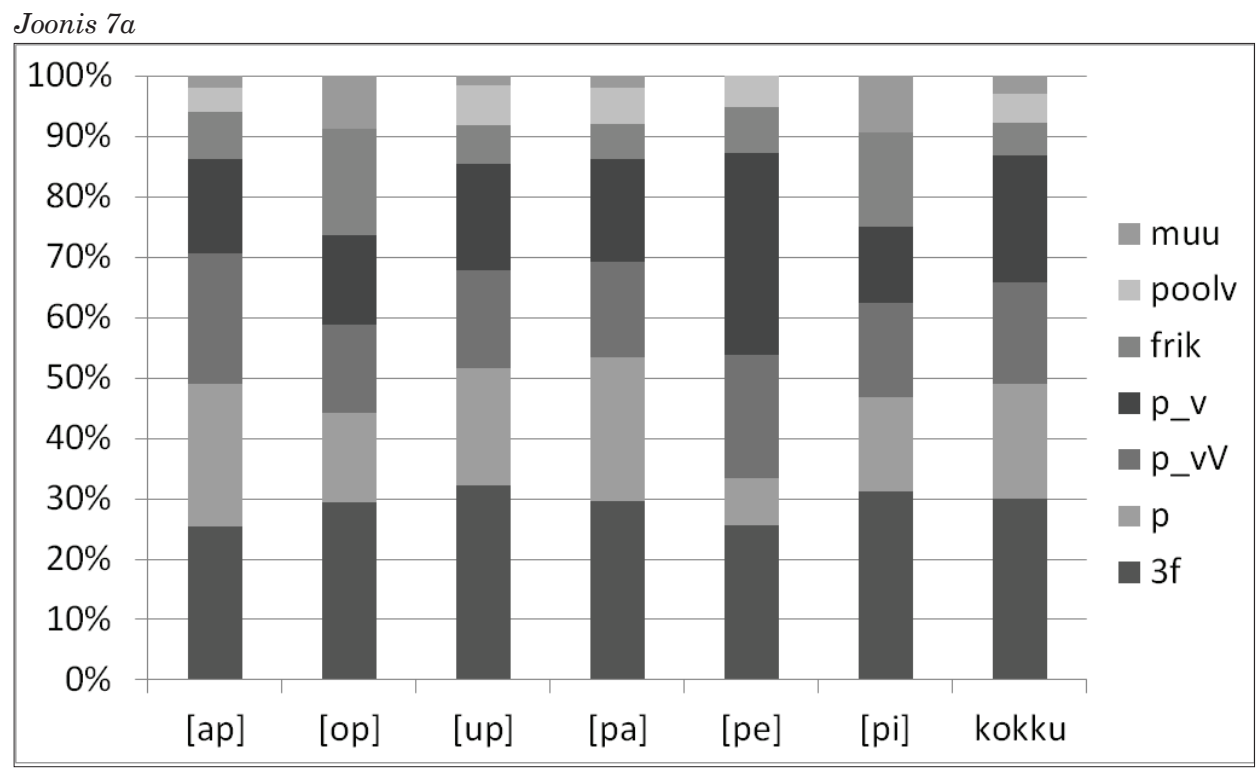



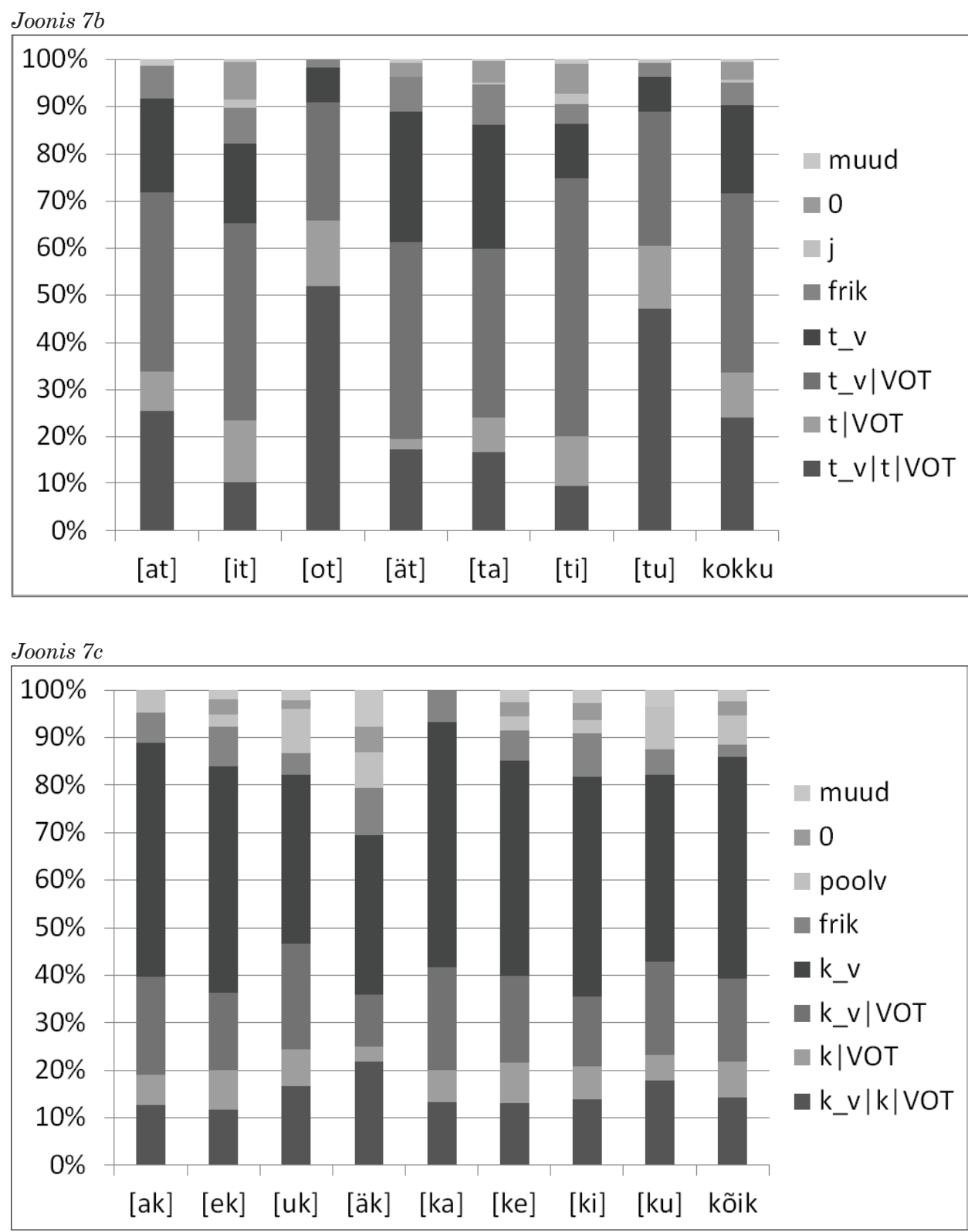

Joonis 7a-c. Allofoonide jagunemine foneemide kaupa eelneva ja järgneva vokaali järgi: a) [p] allofoonid; b) [t] allofoonid; c) [k] allofoonid.

Vokaalkontekst mõjutas mõnevõrra allofoonilist jagunemist. [p] ja [k] allofoonide jagunemine oli kõigis vokaalkontekstides üsna sarnane, [t] puhul olid erinevused suuremad. [k] puhul esines [a] ümbruses umbes $10 \%$ rohkem [c_v] allofooni kui teistes kontekstides. [t] puhul esines labiaalvokaalide ümbruses 
palju rohkem poolhelilist allofooni, [i] naabruses aga kõige rohkem helilist allofooni. [i] naabruses esines kõigi klusiilide, eriti [t] puhul rohkem frikatiivistunud ja poolvokaalistunud allofoone.

Allofoonide keskmised kestused ja standardhälbed eelneva vokaali järgi on esitatud tabelis 5 ning keskmised kestused ja standardhälbed järgneva vokaali järgi on esitatud tabelis 6 .

Tabel 5. Sagedasemate allofoonide keskmised kestused millisekundites eelneva vokaali järgi (standardhälbed sulgudes).

\begin{tabular}{|l|l|l|l|l|l|}
\hline & C_v $|\mathbf{C}| \mathbf{V O T}$ & $\mathbf{C} \mid$ VOT & C_v|VOT & c_v & kõik \\
\hline [ap] & $84(19)$ & $75(13)$ & $69(15)$ & $55(14)$ & $68(19)$ \\
\hline [ob] & $92(18)$ & $89(15)$ & $63(15)$ & $54(14)$ & $75(21)$ \\
\hline [up] & $88(15)$ & $56(6)$ & $65(16)$ & $52(9)$ & $70(21)$ \\
\hline & & & & & \\
\hline [at] & $69(11)$ & $67(14)$ & $58(11)$ & $36(12)$ & $57(19)$ \\
\hline [it] & $71(16)$ & $67(22)$ & $59(14)$ & $38(12)$ & $56(18)$ \\
\hline [ot] & $77(16)$ & $72(19)$ & $73(17)$ & $37(8)$ & $67(22)$ \\
\hline [ät] & $69(12)$ & $62815)$ & $58(12)$ & $42(9)$ & $56(16)$ \\
\hline & & & & & \\
\hline [ak] & $72(21)$ & $74(16)$ & $63(18)$ & $50(9)$ & $59(17)$ \\
\hline [ek] & $81(18)$ & $79(21)$ & $65(16)$ & $47(11)$ & $58(20)$ \\
\hline [uk] & $79(19)$ & $73(19)$ & $67(13)$ & $48(11)$ & $60(21)$ \\
\hline [äk] & $86(25)$ & $94(15)$ & $63(16)$ & $47(9)$ & $63(23)$ \\
\hline
\end{tabular}

Tabel 6. Sagedasemate allofoonide keskmised kestused millisekundites järgneva vokaali järgi (standardhälbed sulgudes).

\begin{tabular}{|c|c|c|c|c|c|}
\hline & C_v|C|VOT & C|VOT & C_v|VOT & C_v & kõik \\
\hline [pa] & 87 (17) & 77 (17) & $68(16)$ & $54(13)$ & $71(21)$ \\
\hline [pe] & $85(13)$ & $85(10)$ & $66(10)$ & 55 (11) & 68 (17) \\
\hline [pi] & 93 (18) & $88(8)$ & $63(15)$ & $54(14)$ & $75(21)$ \\
\hline [ta] & $69(12)$ & $62(15)$ & 58 (14) & 38 (10) & 54 (17) \\
\hline [ti] & $81(14)$ & $74(28)$ & $59(13)$ & $46(12)$ & 60 (18) \\
\hline$[\mathbf{t u}]$ & 77 (16) & 70 (18) & 70 (17) & $40(8)$ & $67(20)$ \\
\hline [ka] & $72(21)$ & 74 (16) & 63 (18) & $50(9)$ & 59 (17) \\
\hline [ke] & $77(17)$ & 74 (18) & 65 (14) & 45 (10) & 57 (19) \\
\hline [ki] & $84(20)$ & $83(23)$ & 66 (16) & 48 (11) & $60(22)$ \\
\hline [ku] & $97(21)$ & $81(13)$ & $71(15)$ & $55(11)$ & $62(21)$ \\
\hline
\end{tabular}


[p] allofoonidest olid pikema kestusega [o]- järgne ja [i]- eelne poolheliline ja helitu allofoon. [k] puhul oli pikima keskmise kestusega [u]-järgne positsioon. Selle kestuse erinevus teistest kontekstidest oli vähesel määral oluline $(\mathrm{p}<.03)$. [t] puhul oli pikima keskmise kestusega labiaalvokaalide naabruses asuv [t], seda nii poolhelilise kui ka helitu allofooni puhul. Kõik [t] järgnevast vokaalist sõltuvad keskmised kestused erinesid statistiliselt olulisel määral (kõigil juhtudel $\mathrm{p}<.01$ ), eelnevast vokaalist sõltuvate keskmiste kestuste osas oli [o] järgne [t] peaaegu kõigi allofoonide korral pikema kestusega, kestuste erinevused olid statistiliselt olulised $(\mathrm{p}<.01)$.

Eelneva vokaali mõju sulufaasi kestusele on toodud tabelis 7 .

Tabel 7. Vallandumisfaasiga allofoonide sulufaasi keskmised kestused millisekundites eelneva vokaali järgi (standardhälbed sulgudes).

\begin{tabular}{|l|l|l|l|l|}
\hline & C_v $|\mathbf{C}| \mathbf{V O T}$ & $\mathbf{C} \mid$ VOT & C_v|VOT & kõik \\
\hline [ap] & $64(11)$ & $50(16)$ & $49(10)$ & $56(14)$ \\
\hline [ob] & $68(18)$ & $63(5)$ & $43(12)$ & $63(15)$ \\
\hline [up] & $65(16)$ & $53(16)$ & $42(10)$ & $58(16)$ \\
\hline & & & & \\
\hline [at] & $48(12)$ & $44(7)$ & $38(11)$ & $42(12)$ \\
\hline [it] & $48(14)$ & $36(20)$ & $35(11)$ & $37(14)$ \\
\hline [ot] & $56(16)$ & $52(15)$ & $38(12)$ & $48(16)$ \\
\hline [ät] & $53(12)$ & $33(12)$ & $34(11)$ & $38(14)$ \\
\hline & & & & \\
\hline [ak] & $50(13)$ & $41(19)$ & $39(15)$ & $48(12)$ \\
\hline [ek] & $51(15)$ & $44(13)$ & $37(12)$ & $47(12)$ \\
\hline [uk] & $53(16)$ & $43(15)$ & $39(11)$ & $49(13)$ \\
\hline [äk] & $54(18)$ & $47(10)$ & $43(13)$ & $49(13)$ \\
\hline
\end{tabular}

Eelneva vokaali mõju sulufaasi kestusele. [t] puhul ilmnes erinevus eesvokaalidele [i], [æ] ja tagavokaalidele [a], [o] järgnevate sulgude kestuses. Tagavokaalidele järgnevad sulufaasid olid pikema kestusega kõigi allofoonide puhul, erinevused olid statistiliselt olulised helitu allofooni puhul $(\mathrm{p}<.01)$. [k] puhul sulufaasi kestuse sõltuvus vokaali ees-tagapoolsusest ei avaldunud. [p] ees esinesid ainult tagavokaalid. Poolhelilise allofooni helilise faasi kestus ei sõltunud eelnevast vokaalist ühegi klusiili puhul.

Järgneva vokaali mõju vallandumisfaaside kestustele on esitatud tabelis 8 . 
Tabel 8. Vallandumisfaasiga allofoonide vallandumisfaasi keskmised kestused millisekundites järgneva vokaali järgi (standardhälbed sulgudes).

\begin{tabular}{|l|l|l|l|l|}
\hline VOT & $\mathbf{C} \_\mathbf{v}|\mathbf{C}|$ VOT & $\mathbf{C} \mid$ VOT & C_v $\mid$ VOT & kõik \\
\hline [pa] & $23(9)$ & $23(8)$ & $24(9)$ & $23(8)$ \\
\hline$[\mathbf{p e}]$ & $20(10)$ & $17(2)$ & $17(6)$ & $21(8)$ \\
\hline [pi] & $25(8)$ & $24(8)$ & $20(7)$ & $21(9)$ \\
\hline & & & & \\
\hline$[\mathbf{t a}]$ & $20(6)$ & $30(12)$ & $23(7)$ & $22(7)$ \\
\hline$[\mathbf{t i}]$ & $27(9)$ & $30(11)$ & $23(7)$ & $25(9)$ \\
\hline$[\mathbf{t u}]$ & $20(5)$ & $21(9)$ & $23(16)$ & $22(10)$ \\
\hline & & & & \\
\hline$[\mathbf{k a}]$ & $25(11)$ & $33(6)$ & $24(9)$ & $26(9)$ \\
\hline$[\mathbf{k e}]$ & $26(8)$ & $33(12)$ & $27(9)$ & $28(10)$ \\
\hline$[\mathbf{k i}]$ & $32(12)$ & $32(12)$ & $27(11)$ & $30(12)$ \\
\hline$[\mathbf{k u}]$ & $28(4)$ & $31(11)$ & $32(12)$ & $31(9)$ \\
\hline & & & &
\end{tabular}

Üldiselt oli kõige pikema vallandumisfaasiga helitu allofoon, mis on sarnane üldkestustega. [p] vallandumisfaaside kestuste erinevused ei olnud üheski kontekstis statistiliselt olulised, ka ei ilmnenud ühtegi vokaalist sõltuvat kestuserinevust allofoonide vahel. [k] poolhelilise allofooni vallandumisfaasi kestus oli kõige pikem [i] ees, erinevus oli statistiliselt oluline võrrelduna kestustega [a] ja [e] ees $(\mathrm{p}<.05)$. Üsna suur oli [k] helilise allofooni vallandumiste kestuserinevus [a] ja [u] ees, kuid statistiliselt oluliseks see ei osutunud. Olulised järgnevast vokaalist sõltuvad kestuserinevused ilmnesid [t] poolhelilise ja helitu allofooni vallandumisfaasides, poolhelilise vallandumisfaasi kestus [i] ees oli oluliselt pikem kui $[\mathrm{a}] \mathrm{ja}[\mathrm{u}]$ ees $(\mathrm{p}<.01)$ ja helitu allofooni vallandumine [u] ees oli lühem $(\mathrm{p}<.05)$. Ka kõigi esinemuste lõikes oli kõige pikem [i] eelne vallandumine $(\mathrm{p}<.01)$.

\section{Arutelu}

\section{Allofooniline jaotus}

Allofooniline jaotus on sarnane eelmise spontaanse kõne uurimusega (Raasik 2010). Mõnevõrra väiksem on redutseerunud allofoonide hulk (Raasik 2010: [p] redutseerumise määr 42\%, [t] 57\% ja [k] 66\%). Erinevust võib seletada sellega, et Liis Raasik (2010) vaatles kõiki sõnu, mille hulgas oli palju lühikesi grammatilisi sõnu ning ka järgsilpide klusiile. [k] puhul on erinevus väga väike 
(66\% vs 60\%). Samas [t] oli kõigi sõnade arvestuses redutseerunum kui vaid täistähenduslikes sõnades. Kari Suomi ja Einar Meistri (2012) tulemustes on redutseerumise määr palju väiksem (tegemist on loetud kõnega), kuid [k] eristub samamoodi tugevalt (vallandumisfaasi kadu üle 25\% esinemisjuhtudest). Redutseerunud allofoonide hulk võrdlevalt eelmiste samalaadiliste uurimustega on toodud tabelis 9 .

Tabel 9. Redutseerunud allofoonide hulk võrrelduna eelnevate uurimustega.

\begin{tabular}{|l|l|l|l|}
\hline & [p] & [t] & {$[\mathbf{k}]$} \\
\hline Raasik (2010) & $42 \%$ & $57 \%$ & $66 \%$ \\
\hline Suomi ja Meister (2012) & $1,1 \%$ & $3,3 \%$ & $25,9 \%$ \\
\hline praegune & $36 \%$ & $30 \%$ & $61 \%$ \\
\hline
\end{tabular}

Poolheliliste klusiilide sulust oli peaaegu alati heliline algusosa (Davidson (2016) bleed-tüüp), mis viitab eelneva hääliku helilisuse ülekandele. Enamasti on tegemist ilmselt häälekurdude võnkumisega sulu hoidmise alguses toimuva rõhu tõusu ajal (eriti sage [p] esinemustes), vahel jõuavad häälekurdude või muu suuruumi tekitatud võnked kõnetraktist välja alles pärast häälekurdude võnkumise lõppu.

Redutseerumise suur määr on suures osas mõjutatud tõenäoliselt sulgude lühikesest kestusest. Läbiva helilisuse puhul ei teki sulg täielikult ja häälekurrud jäävad võnkuma, või lõppeb võnkumine nii lühikeseks ajaks, et see akustiliselt ei väljendu. Vallandumisfaasi redutseerumise korral jõuab rõhk sulu jooksul nii vähe tõusta, et vallandumine ei ole akustiliselt eristatav. Mõju võib avaldada ka see, et eesti keeles ei toimu häälikute vastandusi helilisuse ja vallandumisfaasi põhjal. Suomi ja Meistri (2012) tulemusi võis mõjutada katsesituatsioon - tegemist oli loetud lausetega ning testsõnad erinesid omavahel välte alusel.

\section{Kestused}

Foneemide ja allofoonide kestused on vastavuses üldiste füsioloogiliste ja füüsikaliste tõekspidamistega. Kõige pikemad olid bilabiaalse klusiili [p] kestused, kõige lühemad alveolaari [t] omad. Redutseerunud allofoonide kestused olid ootuspäraselt lühemad kui vallandumisfaasiga allofoonidel. Nii foneemide üldkestused kui ka allofoonide keskmised kestused on lähedased Liis Raasiku (2010) tulemustele. Erinevused on vaid paari millisekundised. 
Sulu vallandumiste keskmised kestused on toodud tabelis 10. Kestused on sarnased Raasiku (2010) leidudega. Suomi ja Meistri (2012) eesti ja soome keele lühikesi klusiile käsitleva uurimusega võrreldes on loetud kõnes esinevate klusiilide vallandumisfaaside kestused aga vastupidiselt ootuspärasele hoopis 7-10 ms lühemad kui käesolevas uurimuses (13-19 ms vs 22-29 ms).

Tabel 10. Sulu vallandumiste keskmised kestused millisekundites võrrelduna eelnevate uurimustega.

\begin{tabular}{|l|l|l|l|}
\hline & [p] & [t] & {$[\mathbf{k}]$} \\
\hline Raasik (2010) & 23 & 25 & 29 \\
\hline Suomi ja Meister (2012) & 13 & 16 & 19 \\
\hline praegune & 22 & 23 & 29 \\
\hline
\end{tabular}

Võrrelduna mitmetes uurimustes (Cho \& Ladefoged 1999; Kuzla \& Ernestus 2011; Suomi \& Meister 2012) esitatud infoga eri keelte klusiilide vallandumisfaaside või VOT kestuste kohta, ei ole eesti keele klusiilid erilised, sest variatiivsus on eri keelte vahel ja ka keelte siseselt väga suur. Taehong Cho ja Peter Ladefogedi (1999) esitatud infost tuleb välja, et äärmuslikumad (väga lühikesed ja väga pikad) VOT kestused esinevad enamasti neis keeltes, kus kasutatakse aspiratsioonivastandust. Aspireerimata hääliku VOT on palju lühem kui sama moodustuskohaga aspireeritud hääliku oma. Võib spekuleerida, kas eesti keele loetud kõnes püütakse säilitada kontrasti pika ja lühikese klusiili vahel ja hääldatakse lühikesi klusiile eriti kiiresti.

\section{Rõhu ja vokaalkonteksti mõju}

Rõhuline positsioon mõjutas vähesel määral allofoonilist jagunemist ja vähem kestust. Kõige suuremad erinevused rõhulise ja rõhuta positsiooni vahel hakkasid silma [t] puhul, seda nii allofoonilise jagunemise kui ka kestuste osas. Mittekontrastiivse lauserõhu vähest mõju klusiilide kestusele märkisid ka Kari Suomi ja Einar Meister (2012) eesti keele ning Claudia Kuzla ja Mirjam Ernestus (2011) saksa keele leenisklusiilide kohta. Rohkem mõjutas kestusi häälduskoht ja vähem rõhuline positsioon.

Vokaalkonteksti mõju näitajad on kooskõlas Liis Raasiku (2010) esitatutega (vaatles vaid järgneva vokaali võimalikku mõju). Kõige pikema keskmise kestusega esinemisjuhud olid mõlemas andmestikus labiaalvokaalide ees. Suurim erinevus oli [i] eelse [t] keskmises kestuses - Raasiku (2010) tulemustes oli selle keskmine kestus $73 \mathrm{~ms}$, praeguses $60 \mathrm{~ms}$. Vallandumisfaaside kestused olid 
samuti lähedased, kõige pikemad vallandumised olid [a] ja [i] ees, erinevused kahe uurimuse vahel mõne millisekundised.

Vokaalkonteksti mõjud peegeldavad kõnetrakti universaalseid füsioloogilisi omadusi ja toetavad ka koproduktsiooniteooria vaatepunkte. Lähedase häälduskohaga vokaalide naabruses esineb rohkem vallandumisfaasiga allofoone ja mõjud on suuremad väheliikuva velaari allofoonides. [p] oli reduktsioonile kõige vähem tundlik ning [k] kõige rohkem. Osaliselt vastavad redutseerumismustrid ka DAC-mudeli käsitlusele. [k] redutseerus küll rohkem kui mudeli järgi ennustada võiks, kuid samas olid kestused lähedased rõhupositsioonist ja vokaalkontekstist sõltumata, mis viitab võimalikule stabiilsusele. Kontekstimõjudest oli kõige rohkem mõjutatud [t], mis väljendus nii kestuste erinevuses kui allofoonilises jagunemises eri vokaalide naabruses.

\section{Kokkuvõte}

Käesolev uurimus vaatles intervokaalseid lühikesi klusiile eesti keele sagedasemates sõnades. Materjal pärines Tartu Ülikooli eesti keele spontaanse kõne foneetilisest korpusest. Vaatluse all olid allofooniline jaotus ja kestuste erinevused ning rõhu ja vokaalkonteksti võimalikud mõjud.

Üldjoontes on tulemused sarnased teiste samalaadsete uurimuste tulemustega. Kõige vähem redutseerus [p]. [k] puhul oli märgata üldist redutseerumist, see ei olnud oluliselt mõjutatud vokaalkontekstist ega rõhust, ka kestuserinevused olid väiksed. Sulufaasid olid enamasti vähemalt osaliselt heliliseks muutunud. Suurima osakaaluga oli poolheliline klusiil [p] allofoonide hulgas ning vallandumisfaasi säilitanud heliline allofoon [t] allofoonide hulgas.

Kõige rohkem olid vokaalkontekstist ja ka rõhulisest positsioonist mõjutatud [t], mis väljendus nii kestuste erinevuses kui allofoonilises jagunemises eri vokaalide naabruses. Rõhu mõju oli üldiselt vähene.

Materjali piiratuse tõttu ei olnud võimalik vaadelda laiemat hulka vokaalkontekste ning kontrastiivse rõhu mõju spontaankõnes. Kindlasti oleks vaja edaspidi suuremas mahus võrrelda loetud ja spontaanse kõne vallandumisfaasides esile tulnud erinevusi. 


\section{Tänuavaldus}

Artikkel on valminud Haridus- ja Teadusministeeriumi uurimisprojekti IUT 35-1 "Kõnestiilid, lauseprosoodia ja fonoloogiline varieerumine: kirjeldus, teooria ja modelleerimine" ja Eesti-uuringute Tippkeskuse (TK145-CEES) toetusel. Autor tänab anonüümseid retsensente asjakohaste märkuste eest.

\section{Kommentaarid}

$1 \mathrm{http} / / /$ www.keel.ut.ee/et/foneetikakorpus - 13.10.2017.

${ }^{2}$ Osaliselt ja täiesti frikatiivistunud allofoone ei ole eristatud helilisuse alusel.

\section{Kirjandus}

Ariste, Paul 1933. Eesti sulghäälikud k, p, tja b, d, g. Eesti Keel 3, lk 73-82; 4, lk 170-180.

Boersma, Paul \& Weenink, David 2016. Praat: doing phonetics by computer [Computer program] (www.praat.org - 1. detsember 2016).

Browman, Catherine P. \& Goldstein, Louis 1992. Articulatory phonology: an overview. Phonetica 49 (3-4), lk 155-180.

Cho, Taehong \& Ladefoged, Peter 1999. Variation and universals in VOT: evidence from 18 languages. Journal of Phonetics 27 (2), lk 207-229 (doi: 10.1006/jpho.1999.0094).

Cole, Jennifer \& Kim, Heejin \& Choi, Hansook \& Hasegawa-Johnson, Mark 2007. Prosodic effects on acoustic cues to stop voicing and place of articulation: Evidence from Radio News speech. Journal of Phonetics 35 (2), lk 180-209 (doi: 10.1016/j.wocn.2006.03.004).

Davidson, Lisa 2016. Variability in the implementation of voicing in American English obstruents. Journal of Phonetics 54, lk 35-50 (doi: 10.1016/j.wocn.2015.09.003).

Duez, Danielle 1995. On spontaneous French speech: Aspects of the reduction and contextual assimilation of voiced plosives. Journal of Phonetics 23, lk 407-427 (doi: 10.1006/jpho.1995.0031).

Eek, Arvo \& Meister, Einar 1996. Eesti sõnaalguliste sulghäälikute akustika ja tajumine. Keel ja Kirjandus 3-5, lk 164-170, 241-253, 314-321.

Fowler, Carol A. \& Saltzman, Elliot 1993. Coordination and coarticulation in speech production. Language and speech 36 (2-3), lk 171-195 (doi: 10.1177/002383099303600304).

Hualde, José Ignacio \& Simonet, Miquel \& Nadeu, Marianna 2011. Consonant lenition and phonological recategorization. Laboratory Phonology 2 (2), lk 301-329 (doi: 10.1515/ labphon.2011.011). 
Jong, Kenneth J. de 1995. The supraglottal articulation of prominence in English: Linguistic stress as localized hyperarticulation. The Journal of the Acoustical Society of America 97 (1), lk 491-504 (doi: 10.1121/1.412275).

Keating, Patricia A. \& Linker, Wendy \& Huffmann, Marie 1983. Patterns in allophone distribution for voiced and voiceless stops. Journal of Phonetics 11, 1k 277-290.

Kuzla, Claudia \& Ernestus, Mirjam 2011. Prosodic conditioning of phonetic detail in German plosives. Journal of Phonetics 39 (2), lk 143-155 (doi: 10.1016/j.wocn.2011.01.001).

Ladefoged, Peter 2001. Vowels and consonants: an introduction to the sounds of languages. Malden, Mass.: Blackwell.

Lindblom, Björn 1990. Explaining Phonetic Variation: A Sketch of the H\&H Theory. Hardcastle, William J. \& Marchal, Alain (toim). Speech Production and Speech Modelling. Dordrecht: Springer Netherlands, lk 403-439 (doi: 10.1007/978-94-009-2037-8_16).

Moon, Seung-Jae \& Lindblom, Björn 1994. Interaction between duration, context, and speaking style in English stressed vowels. The Journal of the Acoustical Society of America 96 (1), lk 40-55 (doi: 10.1121/1.410492).

Raasik, Liis 2010. Intervokaalsete lühikeste klusiilide laad eesti keele spontaankõnes. Magistritöö. Tartu: Tartu Ülikool (http://www.murre.ut.ee/arhiiv/naita_pilt. php?materjal=kasikiri\&materjal_id=D1628\&sari=D - 18. oktoober 2017).

Recasens, Daniel ja Pallarès, Maria Dolors \& Fontdevila, Jordi 1997. A model of lingual coarticulation based on articulatory constraints. The Journal of the Acoustical Society of America 102 (1), lk 544-561 (doi: 10.1121/1.419727).

Suomi, Kari \& Meister, Einar 2012. A preliminary comparison of Estonian and Finnish plosives. Linguistica Uralica (3), lk 187-193 (doi: 10.3176/lu.2012.3.04).

Torreira, Francisco \& Ernestus, Mirjam 2011. Realization of voiceless stops and vowels in conversational French and Spanish. Laboratory Phonology 2 (2), lk 331-353 (doi: 10.1515/labphon.2011.012).

Wells, John 2015. SAMPA computer readable phonetic alphabet (http://www.phon.ucl. ac.uk/home/sampa/index.html - 12. oktoober 2017). 


\section{Summary}

\section{Variation in the pronunciation of Estonian short plosives and its affecting factors}

\section{Liis Ermus}

Archive administrator and junior researcher, Institute of the Estonian Language liis.ermus@eki.ee

Keywords: acoustic phonetics, coarticulation, Estonian language, plosives, reduction, spontaneous speech, voicedness

Plosives in Estonian have been considered voiceless. However, analysis has shown that short plosives tend to get at least partially voiced and otherwise reduced in connected speech. This seems to be quite a universal tendency in different languages.

The present paper investigates short plosives in intervocalic position in most frequent content words. Phonetic materials were extracted from the Phonetic Corpus of Estonian Spontaneous Speech. Patterns in the reduction of plosives and possible influences of stress and vowel context were investigated.

Two kinds of allophones emerged - those that were fully realised and had a distinguishable release burst, and the reduced ones that had lost the burst phase. The amount of reduced tokens differentiated the velar plosive $[\mathrm{k}]$ from others. As $[\mathrm{p}]$ and [t] both had over $65 \%$ of fully realised tokens, but over $60 \%$ of [k] tokens were reduced. $[\mathrm{k}]$ also had most different allophones. Among fully realised tokens there were voiceless, partially voiced, and fully voiced allophones. The voiceless allophone was the rarest, $19 \%$ tokens of $[\mathrm{p}]$ and only $10 \%$ of $[\mathrm{t}]$ and $[\mathrm{k}]$ were voiceless. Most frequent allophones among phonemes were partially voiced for [p] (29\%), fully voiced for [t] (37\%), and reduced voiced for $[\mathrm{k}](47 \%)$.

Closure durations were related to place of articulation. [p] had the longest average durations and $[\mathrm{t}]$ the shortest. Across all tokens $[\mathrm{k}]$ and $[\mathrm{t}]$ had similar average durations but within allophones durations were closer between $[\mathrm{k}]$ and $[\mathrm{p}]$. Burst durations were the longest, around $30 \mathrm{~ms}$ for $[\mathrm{k}]$ and almost the same duration, between $21-23 \mathrm{~ms}$, for [p] and [t], with the exception of the voiceless allophone [t], which was $27 \mathrm{~ms}$. Closure durations differed significantly between $[\mathrm{p}]$ and $[\mathrm{t}]$ and burst durations were significantly different between $[\mathrm{k}]$ and other phonemes.

Stressed positions included both lexical and contrastive stresses. Stress had some effect on the allophonic distribution but almost none on durations. As expected, there were more voiceless and partially voiced tokens in stressed position and more reduced tokens and total loss in unstressed position. Differences were the biggest for $[t]$ and the smallest for $[\mathrm{k}]$. Durations differed very little, whereas none were statistically significant.

Vowel context had some influence on allophonic distribution. The influence was the biggest on [t]. Overall, there were more fricative and approximant tokens around [i]. [t] had more partially voiced tokens and less voiced tokens around labial vowels [o, u]. There were more reduced [k] tokens around [a] and [i]. On durations the vowel context again influenced $[t]$ the most. Durations between all vowel contexts were statistically different for $[\mathrm{t}](\mathrm{p}<.01)$; the longest durations appeared after [i]. 
In general, the present study confirms the results of the previous ones. Allophonic distribution is very similar to the previous study of Estonian spontaneous speech. Closures were at least partially voiced in most cases which refer to carry-over voicing of the previous vowel. Vocal cord vibration stops for a very brief time or does not stop at all during short closure times. Burst durations appear to be longer in spontaneous speech than in read speech. Little influence of stress is in accordance with findings in the studies on Estonian and some other languages. Vowel influences were dependent on the place of articulation. Bilabial [p] was the least affected both in allophonic variation and in durations. Velar $[\mathrm{k}]$ was influenced by the vowel context but it mostly occurred in whole as extensive reduction; different vowels had more effect on the allophonic variation than in the case of [p] but durations were almost unaffected. Influences on [t] mostly occurred as significant duration differences; yet, also some differences in allophonic variation occurred. 